\title{
molecules
}

ISSN 1420-3049

www.mdpi.com/journal/molecules

Editorial

\section{Molecules Best Paper Award 2013}

\section{Derek J. McPhee}

Editor-in-Chief, MDPI AG, Postfach, CH-4005 Basel, Switzerland; E-Mail: mcphee@mdpi.com

Received: 25 January 2013; in revised form: 25 January 2013 / Accepted: 4 February 2013 /

Published: 5 February 2013

Molecules has started to institute a "Best Paper" award to recognize the most outstanding papers in the area of natural products, medicinal chemistry and molecular diversity published in Molecules. We are pleased to announce the second "Molecules Best Paper Award" for 2013. Candidates were chosen by the Editor-in-Chief and selected editorial board members from among all the papers published in 2009. Reviews and research papers were evaluated separately. We are pleased to announce that the following five papers have won the Molecules Best Paper Award in 2013:

\section{Article Award:}

$1^{\text {st }}$ Prize

Thomas J. Schmidt, Amal M. M. Nour, Sami A. Khalid, Marcel Kaiser and Reto Brun Quantitative Structure-Antiprotozoal Activity Relationships of Sesquiterpene Lactones Molecules 2009, 14(6), 2062-2076; doi:10.3390/molecules14062062

Available online: http://www.mdpi.com/1420-3049/14/6/2062

$2^{\text {nd }}$ Prize

Sebastian Jäger, Holger Trojan, Thomas Kopp, Melanie N. Laszczyk and Armin Scheffler Pentacyclic Triterpene Distribution in Various Plants-Rich Sources for a New Group of Multi-Potent Plant Extracts

Molecules 2009, 14(6), 2016-2031; doi:10.3390/molecules14062016

Available online: http://www.mdpi.com/1420-3049/14/6/2016

$3^{\text {nd }}$ Prize

\section{Linghua Meng, Yves F. Lozano, Emile M. Gaydou and Bin Li}

Antioxidant Activities of Polyphenols Extracted from Perilla frutescens Varieties

Molecules 2009, 14(1), 133-140; doi:10.3390/molecules14010133

Available online: http://www.mdpi.com/1420-3049/14/1/133 


\section{Review Award:}

$1^{\text {st }}$ Prize

\section{Barbara Vu, Miao Chen, Russell J. Crawford and Elena P. Ivanova}

Bacterial Extracellular Polysaccharides Involved in Biofilm Formation

Molecules 2009, 14(7), 2535-2554; doi:10.3390/molecules14072535

Available online: http://www.mdpi.com/1420-3049/14/7/2535

$2^{\text {nd }}$ Prize

\section{Ichiro Minami}

Ionic Liquids in Tribology Bacterial

Molecules 2009, 14(6), 2286-2305; doi:10.3390/molecules14062286

Available online: http://www.mdpi.com/1420-3049/14/6/2286

The prize awarding committee merits the article "Quantitative Structure-Antiprotozoal Activity Relationships of Sesquiterpene Lactones" as "...they did not overstate the case for the compounds as antiparasitics, they tested a nice selection of sesquiterpene lactones and tested multiple parasites...". The article "Pentacyclic Triterpene Distribution in Various Plants-Rich Sources for a New Group of Multi-Potent Plant Extracts" was "...a well written paper describing in depth work on the heretofore neglected pentacyclic triterpenes and their biological activities...". The review "Bacterial Extracellular Polysaccharides Involved in Biofilm Formation" provided "...a timely review on a topic whose importance in infectious diseases and bacterial resistence is increasing ...".

We believe these five exceptional papers represent valuable contributions to Molecules and the scientific literature. On behalf of the Prize Awarding Committee and the Editorial Board of Molecules, we would like to congratulate these five teams for their excellent work. In recognition for their accomplishment, Dr. Thomas J. Schmidt, Dr. Sebastian Jäger and Dr. Yves F. Lozano will receive prizes of 1,000, 800 and $600 \mathrm{CHF}$, respectively, and the privilege of publishing an additional open access format paper of their choice free of charge in Molecules. Dr. Elena P. Ivanova and Dr. Ichiro Minami will be awarded the privilege of publishing an additional research paper free of charge in open access format in Molecules.

Prize Awarding Committee

Editor-in-Chief

Dr. Derek J. McPhee

MDPI AG, Postfach, CH-4005 Basel, Switzerland

E-Mail: mcphee@mdpi.com

Editorial Board Member, Section "Natural Products"

Dr. John A. Beutler

Molecular Targets Laboratory, Bldg 1052 Rm 110 NCI at Frederick, Frederick, MD 21702-1201, USA E-Mail: beutlerj@mail.nih.gov 
Editorial Board Member, Section 'Medicinal Chemistry'

\section{Prof. Dr. Jarkko Rautio}

School of Pharmacy, University of Eastern Finland, P.O. Box 1627, 70211 Kuopio, Finland E-Mail: jarkko.t.rautio@uef.fi

Editorial Board Member, Section 'Organic Synthesis'

\section{Prof. Dr. Osmo E. O. Hormi}

Department of Chemistry, University of Oulu, Linnanmaa, P.O.Box 333, FIN-90570 Oulu, Finland E-Mail: osmo.hormi@oulu.fi

(C) 2013 by the authors; licensee MDPI, Basel, Switzerland. This article is an open access article distributed under the terms and conditions of the Creative Commons Attribution license (http://creativecommons.org/licenses/by/3.0/). 